\title{
Morphology of Modified Biochar and Its Potential for Phenol Removal from Aqueous Solutions
}

\author{
Kostas A. Komnitsas * and Dimitra Zaharaki \\ School of Mineral Resources Engineering, Technical University of Crete, Chania, Greece
}

In the present study, the efficiency of phenol removal from synthetic aqueous solutions by chemically modified biochar with the use of $1 \mathrm{M} \mathrm{KOH}$ or $1 \mathrm{M} \mathrm{FeCl}_{3}$ was investigated. Initially, biochar was produced after slow pyrolysis of three different agricultural wastes, namely pistachio (Pistacia vera L.) shells, pecan (Carya illinoinensis) shells, and wood sawdust. The quality of biochar was assessed by evaluating its main properties, such as $\mathrm{pH}$, surface area, porosity and $\mathrm{C}$ content. X-ray diffraction (XRD), Scanning Electron Microscopy (SEM), and Fourier Transform Infrared Spectroscopy (FTIR) were used for the identification of biochar's structure. The efficiency of phenol removal from synthetic solutions was assessed with the use of kinetic and equilibrium experiments. The experimental results show that the $\mathrm{KOH}$-modified biochar exhibited the highest phenol removal efficiency. Hydrophobic sorption on its surface is the main phenol removal mechanism. The pseudo-second order model fits best the kinetic data, while the Freundlich model, as deduced from an equilibrium study describes very well sorption of phenols on all biochars examined.

Ioannis Konstantinos Kalavrouziotis, Hellenic Open University, Greece Teresa Hernandez, Consejo Superior de Investigaciones Cientificas, Spain

*Correspondence: Kostas A. Komnitsas komni@mred.tuc.gr

Specialty section:

This article was submitted to

Wastewater Management, a section of the journal

Frontiers in Environmental Science

Received: 22 February 2016 Accepted: 22 March 2016

Published: 08 April 2016

Citation: Komnitsas KA and Zaharaki D (2016) Morphology of Modified Biochar and Its Potential for Phenol Removal from

Aqueous Solutions.

Front. Environ. Sci. 4:26.

doi: 10.3389/fenvs.2016.00026

\section{INTRODUCTION}

Biochar is a carbon rich and porous material which is produced by thermal conversion of biomass in low oxygen atmosphere at temperature usually not exceeding $600^{\circ} \mathrm{C}$. Slow pyrolysis of biomass has the advantage of retaining almost half of its carbon in stable biochar (Manyà, 2012; Kim et al., 2013). Biochar can be produced in every country using various raw materials including energy crops (e.g., corn, cereals, wood pellets, and oilseed rape), agricultural wastes (e.g., wheat straw, rice husk, waste wood, pistachio, peanut, hazelnut shells, and manure) and other wastes including sewage sludge (Liu et al., 2012; Moussavi and Khosravi, 2012; Agrafioti et al., 2013, 2014; Inyang et al., 2014; Frišták et al., 2015).

Biochar is an environmentally friendly material and may exhibit similar properties with activated carbon. Due to its chemical and biological stability it may be utilized as carbon sink in soils for thousands of years. Also, biochar's ability to retain nutrients is considered very important in terms of improving soil fertility and crop productivity (Steiner et al., 2008; Sánchez et al., 2009; Cayuela et al., 2013; Kloss et al., 2014; Sánchez-García et al., 2014).

Due to its strong adsorption capacity, which is related to the large surface area and the presence of negatively charged organic functional groups, biochar can be used as adsorbent for the removal of various contaminants from wastewaters. Contaminants may include metals such as $\mathrm{Pb}, \mathrm{Cu}, \mathrm{Zn}, \mathrm{As}$, $\mathrm{Ni}$, and $\mathrm{Cd}$, as well as organic compounds, such as pesticides and phenols. Adsorption on biochar 
may be considered as a feasible approach due to its high efficiency, low cost, ease of application and minor by-product generation compared to traditional alternatives (Beesley et al., 2011; Yu et al., 2015).

Phenolic compounds which are present in various concentrations in several waste streams, e.g., $0.5-24 \mathrm{~g} \cdot \mathrm{L}^{-1}$ in olive mill wastewater (OMW), cause toxic effects on aquatic organisms, bacteria and yeast and prevent seed germination. They are reported as human carcinogens, exhibit poor biodegradability and may also cause long-term ecological damage (Bayramoglu et al., 2009; Di Bene et al., 2013; Inyang and Dickenson, 2015). The removal of phenolic compounds with the use of biochar was reported so far in a limited number of studies. According to Mubarik et al. (2016), highly porous biochar produced from sugarcane bagasse can be used as efficient and low-cost adsorbent to remove 2,4,6-trichlorophenol from stock solutions. The potential of biochar produced from switchgrass, hardwood and softwood on removing phenols was mainly related to its microporous surface (Han et al., 2013). Rice straw biochar was used to decrease the concentration of pentachlorophenol in leachates produced from contaminated sediments which were then used to increase the germination rate of wheat seeds (Lou et al., 2011). Biochar produced after pyrolysis of municipal wastewater biosolids removed effectively halogenated phenols, while its sorption capacity was improved at lower solution $\mathrm{pH}$ (Oh and Seo, 2016). Sewage sludge biochar showed excellent adsorption capacity for sulfonated methyl phenol resins which are used as additive in drilling fluids (Liu et al., 2015). Also, biochar prepared from paper mill sludge was used for the removal of pentachlorophenol by simultaneous adsorption and dechlorination (Devi and Saroha, 2015).

According to the Federal Register of Environmental Protection Agency (Environmental Protection Agency, 1995), the benchmark established for the content of total phenols in stormwater discharge is $1 \mathrm{mg} \cdot \mathrm{L}^{-1}$. In Greece, no limits for phenol disposal in water receivers have been so far established. Also, no health-based thresholds for the concentration of phenols in drinking water have been proposed; an indicative acceptable value of $0.5 \mu \mathrm{g} \cdot \mathrm{L}^{-1}$ has been proposed in accordance with the Council Directive 98/83/EC on the quality of water intended for human consumption (Greek Government Gazette, $2007)^{1}$. According to the Canadian Soil Quality Guidelines the recommended concentration of phenols in soils to avoid adverse effects is $3.8 \mathrm{mg} \cdot \mathrm{kg}^{-1}$ (Canadian Council of Ministers of the Environment, 2007).

Chemical modification of biochar with the use of acids, bases or polymers usually enhances its adsorption efficiency. The so called modified/activated/engineered biochars may be produced by treating the feedstock either prior to or after pyrolysis. The final product is characterized by increased surface area, modified chemical functionality and presence of high-affinity adsorption sites which enhance chemical bonding with contaminants (Mayer et al., 2014; Wang et al., 2015).

${ }^{1}$ Council Directive 98/83/EC of 3 November 1998. On the quality of water intended for human consumption.
According to Qian et al. (2013), Al-modified crop straw biochar resulted in adsorption of larger amounts of As(V) from aqueous solutions at $\mathrm{pH}<7$, in comparison with the respective non-modified biochar. High As adsorption potential was also shown for modified corn straw biochar which was prepared by pyrolysis of the raw material that was initially soaked in aqueous $\mathrm{KMnO}_{4}$ solution $\left(0.079 \mathrm{~mol} \cdot \mathrm{L}^{-1}\right)$ (Yu et al., 2015). Sun et al. (2015) have shown that eucalyptus saw dust biochar modified with citric, tartaric, and acetic acids can efficiently remove methylene blue from aqueous solution. Also, more than $90 \% \mathrm{NO}_{3}$ removal was attained using biochar produced from conocarpus green waste which was chemically modified with magnesium and iron oxides prior to pyrolysis (Usman et al., 2016). Finally, hydrogel-biochar composites modified with $\mathrm{NaCl}$ were found to improve sorption of phenols (Karakoyun et al., 2011).

Various models have been widely applied to describe adsorption of contaminants from solutions and elucidate the mechanisms involved. These models are based either on solution concentration, e.g., first-order, second-order reversible or irreversible and pseudo-first, pseudo-second order or on adsorption efficiency, e.g., Lagergren's first-order equation, Zeldowitsch's model and Elovich's equation (Ho and McKay, 1999; Ho, 2006a,b; Dari et al., 2015; Zahir et al., 2015).

The present paper aims to characterize the morphology of biochar modified with the use of either $1 \mathrm{M} \mathrm{KOH}$ or $1 \mathrm{M} \mathrm{FeCl}_{3}$ and also assess, through kinetic and equilibrium experiments, the effect of modification on the removal of phenols from synthetic solutions.

\section{METHODOLOGY}

\section{Raw Materials}

The raw materials used for the production of biochar were (i) pistachio (Pistacia vera L.) shells (PIr) from trees cultivated in Aegina island, Greece (ii) pecan (Carya illinoinensis) shells (PEr) from trees cultivated in the region of Chania, island of Crete, Greece and (iii) pine wood sawdust (SDr) obtained from a carpentry workshop located in Akrotiri, Chania, Crete.

\section{Biochar Production and Characterization}

The raw materials were oven dried (ON-O2, MEDLINE) for 24 $\mathrm{h}$ prior to use in order to remove moisture. Then, slow pyrolysis was carried out in a modified laboratory furnace N-8L SELECTA at $400^{\circ} \mathrm{C}$ for $60 \mathrm{~min}$ using porcelain capsules. The heating rate was $10^{\circ} \mathrm{C} \cdot \mathrm{min}^{-1}$. Nitrogen was purged in the oven for $60 \mathrm{~min}$ at a rate of $100 \mathrm{~cm}^{3} \cdot \mathrm{min}^{-1}$ to remove air. The obtained biochars from pistachio shells, pecan shells and sawdust are hereinafter mentioned as PI, PE, and SD, respectively.

All biochars were pulverized using a FRITSCH pulverizer to obtain grain size $<100 \mu \mathrm{m}$, as evaluated using a Mastersizer $S$ (Malvern Instruments) particle size analyzer. The following parameters were determined in feedstocks and biochars. Pyrolysis yield $\left(\mathrm{y}_{\mathrm{P}}\right)$ was determined from the \% weight loss after heating. $\mathrm{pH}$ was measured using a solid:liquid ratio of $1: 10$ with a Hanna 211 pH/Eh meter. Porosity (\%) was measured by mercury intrusion porosimetry using a Micromeritics AutoPore 9400 
porosimeter. Brunauer-Emmett-Teller (BET) surface area was measured using a NOVA Surface Area Analyzer (Quantachrome instruments). The elemental C, H, S, and $\mathrm{N}$ analysis was carried out in a Flash 2000 Elemental Analyzer Thermo Scientific calibrated using BBOT standards (2,5-Bis(5-tert-butyl-2-benzooxazol-2-yl)thiophene) containing carbon; the oxygen content was subsequently calculated as the difference. Biochars were subjected to thermogravimetric (TG) analysis using a differential thermogravimetric analyzer TGA-6/DTG of Perkin Elmer as described in detail in Komnitsas et al. (2015, 2016); volatile matter (VM) and ash content were determined, while char fraction (100\%-\%VM) and fixed carbon (FC) content (\% char-\% ash content) were calculated.

The following analyses were also carried out for feedstock and biochar characterization. X-ray diffraction (XRD) analysis was performed using a Bruker AXS (D8 Advance type) diffractometer with $\mathrm{Cu}$ tube, scanning range from $4^{\circ}$ to $70^{\circ} 2 \theta$, step $0.02^{\circ}$ and measuring time $0.2 \mathrm{~s} / \mathrm{step}$. The qualitative analysis was assessed with the use of the DIFFRACplus EVA v. 2006 software and the Powder Diffraction File (PDF-2) database. SEM analysis was performed with a JEOL 6380LV scanning electron microscope equipped with an EDS INCA microanalysis system with low vacuum, pressure $30 \mathrm{~Pa}$, voltage $20 \mathrm{kV}$ and $10-12 \mathrm{~mm}$ working distance from the detector. FTIR analysis was carried out using pellets produced after mixing a pulverized sample of feedstock or biochar with $\mathrm{KBr}$ at a ratio of 1:100 w/w, using a Perkin-Elmer Spectrum 1000 spectrometer (USA).

\section{Modification of Biochar}

Pulverized biochars PI, PE, and SD were subjected to chemical modification. In brief, $10 \mathrm{~g}$ of each biochar were added in 250 $\mathrm{mL}$ of $1 \mathrm{M} \mathrm{KOH}(\mathrm{pH} 13.5)$ or $1 \mathrm{M} \mathrm{FeCl}_{3}$ ( $\left.\mathrm{pH} 0.4\right)$ and the solution stirred with magnetic stirrers (Agimatic-ED, Spain) at $350 \mathrm{rpm}$ for $24 \mathrm{~h}$ at room temperature. The supernatant solution was discarded and the solid material was collected and washed repeatedly with distilled water to remove excess of $\mathrm{KOH}$ or $\mathrm{FeCl}_{3}$ and then was oven-dried at $40^{\circ} \mathrm{C}$ for $24 \mathrm{~h}$. The biochars modified with $\mathrm{KOH}$ or $\mathrm{FeCl}_{3}$ were named as PI-K, PE-K, SD-K or PI-F, PE$\mathrm{F}, \mathrm{SD}-\mathrm{F}$, respectively, and characterized as previously described.

\section{Kinetic and Equilibrium Studies}

Kinetic and equilibrium experiments were carried out using biochars PI, PE, and SD and modified biochars PI-K, PE-K, SD-K and PI-F, PE-F, SD-F. A synthetic phenol solution $100 \mathrm{mg} \cdot \mathrm{L}^{-1}$ was prepared and used in all experiments by dissolving the required quantity of phenol $\mathrm{C}_{6} \mathrm{H}_{5} \mathrm{OH}$ (Sigma Aldrich, Germany) in distilled water.

For the kinetic experiments the adsorbent-biochar concentration used was $5 \mathrm{~g} \cdot \mathrm{L}^{-1}$. The selection of this specific concentration was based on previous studies carried out by the authors (Komnitsas et al., 2015, 2016). Agitation took place in $200 \mathrm{~mL}$ glass beakers at room temperature at $350 \mathrm{rpm}$, using a Vibromatic (Spain) rocking mixer. Reference tests were also carried out using $5 \mathrm{~g} \cdot \mathrm{L}^{-1}$ of activated carbon (AC) (Donau Chemie, Austria), which is an established commercial adsorbent. At various time intervals $(0.5,1,2,5,18,24,48$, and $72 \mathrm{~h}) 10$ $\mathrm{mL}$ of liquid samples were withdrawn and filtered through
Whatman filters $(0.45 \mu \mathrm{m})$ for the determination of phenol concentration in solution using the Folin-Ciocalteu method (Box, 1983) and a SMART3 Lamotte, USA, colorimeter. All tests and measurements were carried out in triplicate.

Equilibrium experiments were carried out using four adsorbent-biochar concentrations, namely $0.5,1,2$, and $5 \mathrm{~g} \cdot \mathrm{L}^{-1}$, while the adsorbed phenol concentration was calculated as the difference between the initial and the concentration at equilibrium in liquid phase. The other experimental conditions were similar to those described previously for the kinetic experiments.

\section{RESULTS AND DISCUSSION \\ Characterization of Biochars}

The characterization of the three raw materials, namely pistachio shells (PIr), pecan shells (PEr), and sawdust (SDr) as well as of the biochars produced after pyrolysis at $400^{\circ} \mathrm{C}$ for $60 \mathrm{~min}$ (PI, $\mathrm{PE}, \mathrm{SD})$ and the modified biochars using $1 \mathrm{M} \mathrm{KOH}$ (PI-K, PE-K, $\mathrm{SD}-\mathrm{K}$ ) or $1 \mathrm{M} \mathrm{FeCl}_{3}$ (PI-F, PE-F, SD-F) is presented in Table 1. It is shown that the pyrolysis yield varies between 17.7 and $34.7 \%$ depending on pyrolysis temperature, heating rate and residence time (Komnitsas et al., 2015; Tripathi et al., 2016).

The paste $\mathrm{pH}$ (biochar:water ratio 1:10 w/w) of biochars PI, $\mathrm{PE}$ and SD is $6.4,6.1$, and 4.8 , respectively, which is higher compared to the paste $\mathrm{pH}$ of the respective raw materials. Slightly lower values are obtained for the $\mathrm{KOH}$-modified biochars, while a further slight decrease of $\mathrm{pH}$ is shown for the $\mathrm{FeCl}_{3}$-modified biochars due to the acidity of the ferric chloride solution. The volatile matter (VM) content of all biochars is substantially decreased compared to the raw materials, while the VM content of biochar PI is higher compared to PE and SD biochars. The char and fixed carbon (FC) contents increased in all biochars due to their higher content of bioavailable carbon. The ash content (difference between char and FC content), which expresses the inorganic matter content, is low and varies in all raw materials and biochars between 1.6 and $1.8 \%$. The $\mathrm{C}$ content in all biochars increases substantially compared to the raw materials, while the hydrogen, nitrogen, and oxygen contents decrease accordingly. Decreased $\mathrm{H} / \mathrm{C}$ and $\mathrm{O} / \mathrm{C}$ ratios were obtained compared to those present in the raw materials, while chemical modification resulted in a further decrease of the $\mathrm{O} / \mathrm{C}$ ratios, as also shown in other studies (Dehkhoda et al., 2016). Finally, it is mentioned that no sulfur was identified in any of the raw materials used.

Increased porosity of all biochars was also shown (29.3, 25.3, and $22.5 \%$, for PI, PE, and SD, respectively) compared to the raw materials due to the transformation of aliphatic $\mathrm{C}$ structures to aromatic C structures (Brewer et al., 2014; Gray et al., 2014). The porosity was substantially increased for all and especially the $\mathrm{KOH}$-modified biochars. The surface area of the non-modified biochars followed the sequence $\mathrm{PI}>\mathrm{PE}>\mathrm{SD}$, and was also significantly increased after modification following the same trend, namely PI-K $\left(572.4 \mathrm{~m}^{2} \cdot \mathrm{g}^{-1}\right)>$ PE-K $\left(397.3 \mathrm{~m}^{2} \cdot \mathrm{g}^{-1}\right)$ $>$ SD-K $\left(124.6 \mathrm{~m}^{2} \cdot \mathrm{g}^{-1}\right)$ and PI-F $\left(421.5 \mathrm{~m}^{2} \cdot \mathrm{g}^{-1}\right)>$ PE-F $(351.6$ $\left.\mathrm{m}^{2} \cdot \mathrm{g}^{-1}\right)>\operatorname{SD}-\mathrm{F}\left(110.8 \mathrm{~m}^{2} \cdot \mathrm{g}^{-1}\right)$. Porosity and surface area are parameters of major importance in terms of adsorption efficiency, as discussed in the following sections. 
TABLE 1 | Characterization of pistachio shells (PIr), pecan shells (PEr), sawdust (SDr), and produced biochars.

\begin{tabular}{|c|c|c|c|c|c|c|c|c|c|c|c|c|}
\hline & PIr & PI & PI-K & PI-F & PEr & PE & PE-K & PE-F & SDr & SD & SD-K & SD-F \\
\hline $\mathrm{y}_{\mathrm{P}}, \%$ & - & 31.4 & - & - & - & 34.7 & - & - & - & 17.7 & - & - \\
\hline $\mathrm{pH}$ & 4.2 & 6.4 & 6.1 & 5.7 & 4.8 & 6.1 & 5.8 & 5.6 & 3.7 & 4.8 & 4.6 & 4.4 \\
\hline VM, \% & 86 & 46.3 & - & - & 71.3 & 38.9 & - & - & 89.6 & 39.9 & - & - \\
\hline Char, \% & 14 & 53.7 & - & - & 28.7 & 61.1 & - & - & 10.4 & 60.1 & - & - \\
\hline FC, \% & 12.4 & 52 & - & - & 27 & 59.3 & - & - & 8.8 & 58.4 & - & - \\
\hline Ash, \% & 1.6 & 1.7 & - & - & 1.7 & 1.8 & - & - & 1.6 & 1.7 & - & - \\
\hline$\%$ C & 45.93 & 73.42 & 78.24 & 75.4 & 47.4 & 71.6 & 75.3 & 72.8 & 46.7 & 65.2 & 72.9 & 67.3 \\
\hline$\% \mathrm{H}$ & 6.04 & 2.93 & 3.07 & 2.95 & 5.39 & 2.65 & 2.75 & 2.63 & 5.81 & 2.08 & 2.19 & 2.11 \\
\hline$\% N$ & 0.42 & 0.21 & 0.74 & 0.71 & 0.63 & 0.6 & 0.76 & 0.72 & 0.51 & 0.32 & 0.39 & 0.36 \\
\hline$\% O$ & 47.61 & 23.44 & 17.95 & 20.94 & 46.58 & 25.15 & 21.09 & 23.85 & 46.98 & 32.4 & 24.52 & 30.23 \\
\hline $\mathrm{H} / \mathrm{C}$ ratio & 0.132 & 0.040 & 0.039 & 0.039 & 0.114 & 0.037 & 0.037 & 0.036 & 0.124 & 0.032 & 0.030 & 0.031 \\
\hline $\mathrm{O} / \mathrm{C}$ ratio & 1.037 & 0.319 & 0.229 & 0.278 & 0.983 & 0.351 & 0.281 & 0.328 & 1.006 & 0.497 & 0.336 & 0.449 \\
\hline Porosity, \% & 15.2 & 29.3 & 49.8 & 41.4 & 12.8 & 25.3 & 34.7 & 29.8 & 10.4 & 22.5 & 27.5 & 26.5 \\
\hline Surface area, $\mathrm{m}^{2} \cdot \mathrm{g}^{-1}$ & - & 196.4 & 572.4 & 421.5 & - & 142.4 & 397.3 & 351.6 & - & 48.7 & 124.6 & 110.8 \\
\hline
\end{tabular}

The XRD analysis of the starting materials and the nonmodified biochars has been presented in detail in previous studies (Komnitsas et al., 2015, 2016). In brief, in all raw materials (PIr, $\mathrm{PEr}$, and SDr) the characteristic amorphous peaks of cellulose, which is one of the structural components of the primary cell wall of green plants, are detected. However, after pyrolysis the intensity of these peaks was reduced. The peaks of residual inorganic phases, such as calcite, quartz, whewellite, halite, and thermonatrite are only visible in non-modified biochars, after partial decomposition of organic matter.

Figure 1 shows the XRD patterns of biochars modified with $\mathrm{KOH}$ or $\mathrm{FeCl}_{3}$ (PI-K, PE-K, SD-K or PI-F, PE-F, SD-F, respectively), which exhibit a more or less elevated background between 15 and $30^{\circ} 2$-theta, due to the presence of organic matter (Cao and Harris, 2010). The cellulose peak is broader and of lower intensity in all biochars, compared to the starting materials, indicating a less ordered structure. Residual inorganic phases, such as quartz and calcite are more easily detected in modified biochars due to the partial decomposition of the organic matter during modification. Sodium carbonate is present in PE-F and PE-K biochars, as a result of atmospheric carbonation; this phase is soluble and disappears when samples are washed with water.

SEM and FTIR analyses were carried out for biochars produced from pistachio shells, which show the highest phenol adsorption capacity compared to biochars produced from pecan shells and wood sawdust, as deduced from the experimental results discussed in the following sections. Indicative SEM images of raw pistachio shells (PIr), biochar PI, KOH-modified biochar $\mathrm{PI}-\mathrm{K}$ and $\mathrm{FeCl}_{3}$-modified biochar PI-F, are shown in Figure 2. The matrix of raw pistachio shells PIr is heterogeneous, while after pyrolysis for the production of PI biochar agglomeration takes place and a porous structure is formed due to the release of volatiles. SEM images of modified biochars (PI-K and PI-F) reveal their microporous structure as a result of their high porosity (49.8\% and 41.4\%, respectively, Table 1). Moreover, very fine particles with an average size of $15 \mu \mathrm{m}$ are present in modified biochars resulting in a substantial increase of the surface area (572.4 and $421.5 \mathrm{~m}^{2} \cdot \mathrm{g}^{-1}$ for PI-K and PI-F, respectively).
The FTIR spectra of raw pistachio shells (PIr), biochar PI, $\mathrm{KOH}$-modified biochar PI-K and $\mathrm{FeCl}_{3}$-modified biochar PI-F, are presented in Figure 3. The respective FTIR spectra band assignments are listed in detail in Table 2. The broad peaks shown in all samples at around $3420 \mathrm{~cm}^{-1}$ indicate the presence of hydroxyl group $(-\mathrm{OH})$ stretching and strong hydrogen bonding, while those at 2920 and $2850 \mathrm{~cm}^{-1}$ are due to aliphatic $\mathrm{C}-\mathrm{H}$ deforming vibration. The band at $1735 \mathrm{~cm}^{-1}$ for PIr is slightly shifted for all biochars to $1700 \mathrm{~cm}^{-1}$ and is assigned to $\nu(C=O)$ vibration in carbonyl group or the presence of carboxylic bonds. The band of PIr at $1630 \mathrm{~cm}^{-1}$, which is due to $\mathrm{C}=\mathrm{O}$ or $\mathrm{C}=\mathrm{C}$ stretching in aromatic groups, is slightly shifted to $1612 \mathrm{~cm}^{-1}$ in modified biochars indicating that chemical interactions occurred on the modified biochar surface. The shifting of the peaks around $1600-1700 \mathrm{~cm}^{-1}$ is also related to the conjunction of the carbonyl groups with the aromatic ring. The band at $1385 \mathrm{~cm}^{-1}$, shown in all patterns, is attributed to $\mathrm{d}(\mathrm{C}=\mathrm{H})$ vibration in alkanes and alkyl groups and is more intense for the modified biochars PI-K and PI-F. In PIr, the band at $1260 \mathrm{~cm}^{-1}$ is attributed to $\mathrm{C}=\mathrm{C}$ stretching while the sharp peak at $1045 \mathrm{~cm}^{-1}$ is mainly attributed to alcohol $\mathrm{C}-\mathrm{O}$ or $\mathrm{Si}-\mathrm{O}-\mathrm{Si}$ functional groups. Both bands almost disappear in all biochars, either due to decomposition of cellulose after pyrolysis at $400^{\circ} \mathrm{C}$ or chemical modification. The bands at $900-600 \mathrm{~cm}^{-1}$ shown mainly in PIr and non-modified biochar PI, are assigned to $\mathrm{C}-\mathrm{H}$ wagging vibrations due to the presence of aromatic and heteroaromatic compounds.

\section{Kinetic Studies}

The kinetics of phenol adsorption on biochars PI, PE, SD and modified biochars PI-K, PE-K, SD-K and PI-F, PE-F, SD-F was studied using the pseudo-first and pseudo-second order Lagergren kinetic models which are described by the linear Equations (1) and (2), respectively:

$$
\begin{array}{r}
\log \left(\mathrm{q}_{\mathrm{e}}-\mathrm{q}_{\mathrm{t}}\right)=\log \mathrm{q}_{\mathrm{e}}-\frac{\mathrm{k}_{1} \mathrm{t}}{2.303} \\
\frac{\mathrm{t}}{\mathrm{q}_{\mathrm{t}}}=\frac{1}{\mathrm{k}_{2} \mathrm{q}_{\mathrm{e}}^{2}}+\frac{\mathrm{t}}{\mathrm{q}_{\mathrm{e}}}
\end{array}
$$




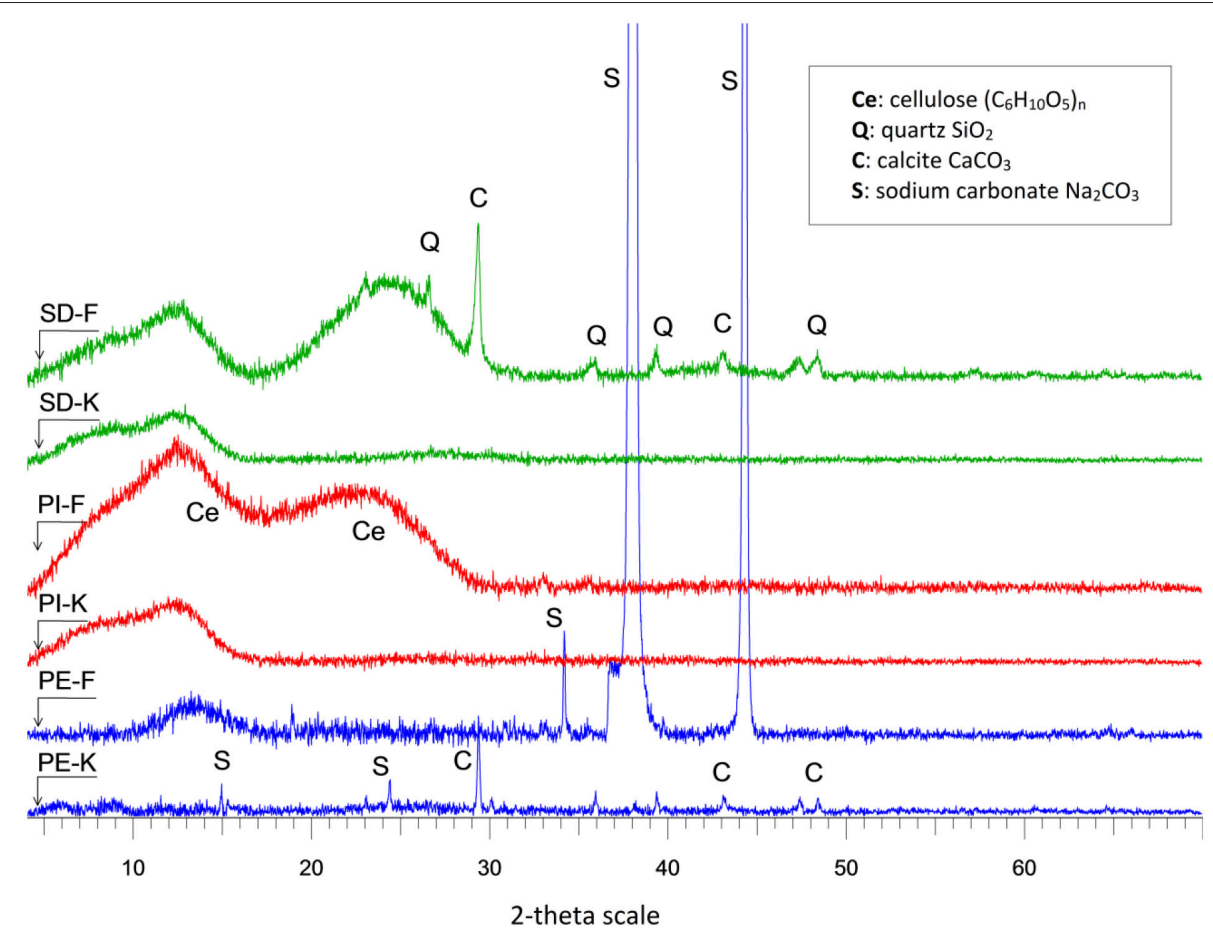

FIGURE 1 | XRD patterns of biochars modified with $1 \mathrm{M} \mathrm{KOH} \mathrm{(PI-K,} \mathrm{PE-K,} \mathrm{SD-K)} \mathrm{or} 1 \mathrm{M} \mathrm{FeCl} 3$ (PI-F, PE-F, SD-F).

TABLE 2 | FTIR spectra band assignments presented in Figure 3.

\begin{tabular}{|c|c|c|}
\hline Band, $\mathrm{cm}^{-1}$ & Assignment & References \\
\hline 3420 & Hydroxyl group $(-\mathrm{OH})$ stretching & Liu et al., 2013 \\
\hline 2850, 2920 & Aliphatic $\mathrm{C}-\mathrm{H}$ deforming vibration & Angin and Şensöz, 2014 \\
\hline 2350 & $\begin{array}{l}\text { Asymmetrical stretching of } \mathrm{CO}_{2} \\
\text { (denotes atmospheric carbonation) }\end{array}$ & Socrates, 2001 \\
\hline 1735,1700 & $\begin{array}{l}\nu(\mathrm{C}=\mathrm{O}) \text { vibration in carbonyl group or } \\
\text { presence of carboxylic bonds }\end{array}$ & $\begin{array}{l}\text { Sharma et al., 2004; Cao } \\
\text { and Harris, } 2010\end{array}$ \\
\hline $\begin{array}{l}1630,1612 \\
1500\end{array}$ & $\begin{array}{l}\text { Aromatic } \mathrm{C}=\mathrm{O} \text { ring stretching (likely } \\
-\mathrm{COOH} \text { ) or } \mathrm{C}=\mathrm{C} \text { stretching of } \\
\text { aromatic groups present in lignin }\end{array}$ & $\begin{array}{l}\text { Mimmo et al., 2014; Yang } \\
\text { and Jiang, } 2014\end{array}$ \\
\hline 1385 & $\begin{array}{l}\delta(\mathrm{C}=\mathrm{H}) \text { vibration in alkanes and alkyl } \\
\text { groups }\end{array}$ & Samsuri et al., 2013 \\
\hline 1260 & $\mathrm{C}=\mathrm{C}$ stretching & Cao and Harris, 2010 \\
\hline 1045 & $\begin{array}{l}\text { Alcohol } \mathrm{C}-\mathrm{O} \text { or aromatic stretching } \\
\text { peak, } \mathrm{O}-\mathrm{H} \text { deformation vibrations, } \\
\text { b-glycosidic bond present in cellulose } \\
\text { and hemicellulose or } \mathrm{Si}-\mathrm{O}-\mathrm{Si} \\
\text { functional groups }\end{array}$ & $\begin{array}{l}\text { Angin et al., 2013; Mimmo } \\
\text { et al., } 2014\end{array}$ \\
\hline $900-600$ & $\mathrm{C}-\mathrm{H}$ wagging vibrations & Ghani et al., 2013 \\
\hline
\end{tabular}

where $\mathrm{q}_{\mathrm{t}}$ and $\mathrm{q}_{\mathrm{e}}\left(\mathrm{mg} \cdot \mathrm{g}^{-1}\right)$ is the uptake of phenols per unit weight of adsorbent at time $t$ and at equilibrium, respectively, $\mathrm{k}_{1}$ $\left(\mathrm{h}^{-1}\right)$ and $\mathrm{k}_{2}\left(\mathrm{~h}^{-1}\right)$ are the rate constants for the pseudo-first and pseudo-second order kinetics, respectively.

The linear plot of $\log \left(q_{e}-q_{t}\right)$ vs. $t$, according to Equation (1), provides $\mathrm{k}_{1}$ and $\mathrm{q}_{\mathrm{e}}$ values for the pseudo-first order model. The plot of $\mathrm{t} / \mathrm{q}_{\mathrm{t}}$ vs. $\mathrm{t}$, according to Equation (2), provides $\mathrm{k}_{2}$ and $\mathrm{q}_{\mathrm{e}}$ for the pseudo-second order model. Parameters for the pseudofirst and pseudo-second order of Lagergren kinetic models, as derived from the experimental tests, are presented in Table 3. Equilibrium in all tests was achieved in $24 \mathrm{~h}$.

As shown in Table 3, for all biochars, modified or not, the pseudo-second order model fits the data much better $\left(R^{2}\right.$ values are higher than 0.998 ) than the pseudo-first order model. These results indicate that the reaction rate is proportional to the number of the active sites present on the adsorbent surface. It is known that adsorption in batch systems is affected by both surface or pore diffusion (Mohan et al., 2007; Li et al., 2010). Additional modeling is required to define which diffusion type is the rate limiting step (Hui et al., 2003).

\section{Adsorption of Phenols on Biochars}

Table 4 shows the \% phenol adsorption from synthetic solution (initial concentration $100 \mathrm{mg} \cdot \mathrm{L}^{-1}$ ) on non-modified biochars PI, $\mathrm{PE}, \mathrm{SD}$ as well as on biochars modified with $1 \mathrm{M} \mathrm{KOH}$ (PI-K, $\mathrm{PE}-\mathrm{K}, \mathrm{SD}-\mathrm{K}$ ) or $1 \mathrm{M} \mathrm{FeCl}_{3}$ (PI-F, PE-F, SD-F). It is shown that for all adsorbent concentrations considered $(0.5,1,2$, and $5 \mathrm{~g}$ $\left.\mathrm{L}^{-1}\right)$, biochars modified with $1 \mathrm{M} \mathrm{KOH}$ exhibit the highest phenol adsorption efficiency.

Experimental data shows that phenols are adsorbed more efficiently on $\mathrm{KOH}$-modified biochars following the sequence $\mathrm{PI}-\mathrm{K}>\mathrm{PE}-\mathrm{K}>\mathrm{SD}-\mathrm{K}$, and the maximum adsorption reaches 76.6, 61.7 , and $46.2 \%$, respectively, when the adsorbent concentration is $5 \mathrm{~g} \cdot \mathrm{L}^{-1}$. Lower adsorbent concentrations result in reduced adsorption efficiency due to the presence of less surface adsorption sites (Wang et al., 2006). 


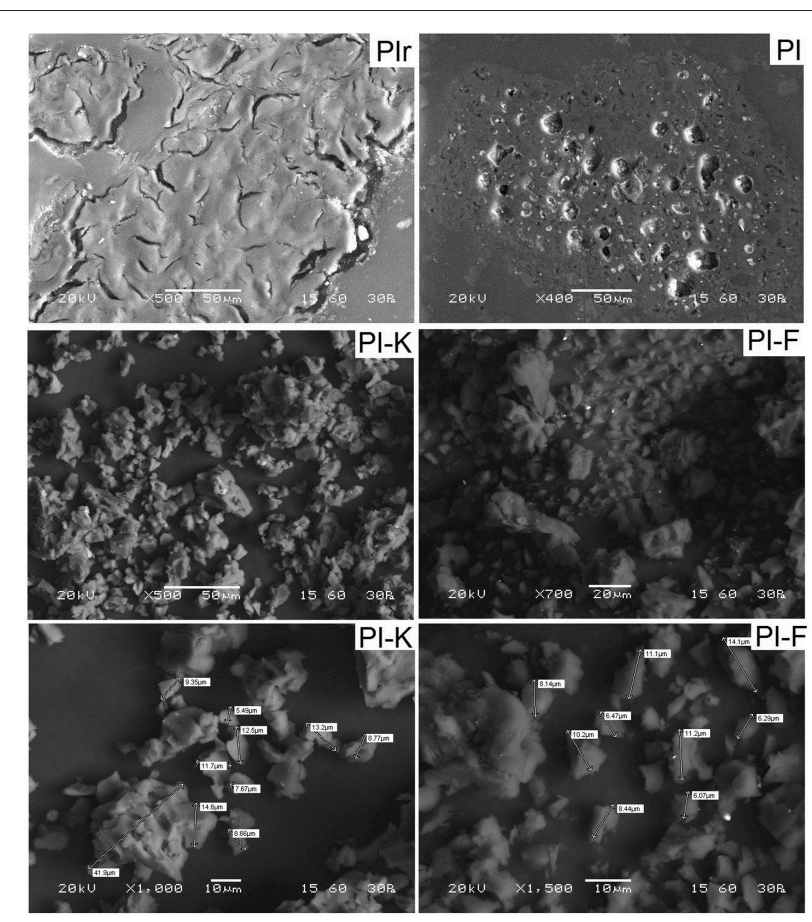

FIGURE 2 | SEM images of raw pistachio shells (PIr) and biochars PI, PI-K (x500, x1000), and PI-F (x700, x1500).

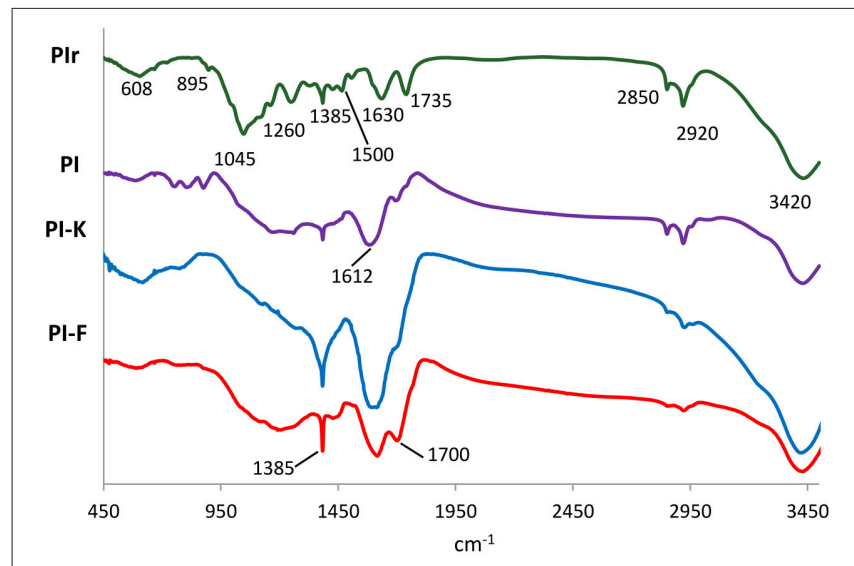

FIGURE 3 | FTIR spectra of raw pistachio shells (PIr) and biochars PI, $\mathrm{PI}-\mathrm{K}$, and PI-F.

The same trend is also noticed for the $\mathrm{FeCl}_{3}$-modified biochars and non-modified biochars, namely PI-F $>$ PE-F $>$ SD-F and $\mathrm{PI}>\mathrm{PE}>\mathrm{SD}$, respectively. Activated carbon, which was used as reference adsorbent, shows quite similar with PI biochar adsorption efficiency, for all adsorbent concentrations used. An important finding of this study is that modification of PI biochar with $\mathrm{KOH}$ or $\mathrm{FeCl}_{3}$ results in better phenol adsorption efficiency than activated carbon. It is mentioned that biochar is a cheap, environment friendly and readily available product that can be easily chemically activated. On the other hand, commercial activated carbon, which is usually prepared from coal, lignite,
TABLE 3 | Parameters for the pseudo-first and pseudo-second order of Lagergren kinetic models for phenols adsorption on biochars PI, PE, SD and modified biochars PI-K, PE-K, SD-K and PI-F, PE-F, SD-F.

\begin{tabular}{|c|c|c|c|c|c|c|}
\hline & \multicolumn{3}{|c|}{ Pseudo-first order } & \multicolumn{3}{|c|}{ Pseudo-second order } \\
\hline & $\mathrm{k}_{1}\left(\min ^{-1}\right)$ & $q_{e}\left(\mathbf{m g} \cdot g^{-1}\right)$ & $R^{2}$ & $\begin{array}{c}\mathrm{k}_{2}\left(\mathrm{~g} \cdot \mathrm{mg}^{-1}\right. \\
\left.\min ^{-1}\right)\end{array}$ & $q_{e}\left(\mathbf{m g} \cdot g^{-1}\right)$ & $R^{2}$ \\
\hline $\mathrm{PI}$ & 0.222 & 6.789 & 0.806 & 0.070 & 10.799 & 0.999 \\
\hline PE & 0.242 & 5.198 & 0.811 & 0.097 & 8.251 & 0.999 \\
\hline SD & 0.318 & 4.120 & 0.862 & 0.151 & 6.614 & 1.000 \\
\hline $\mathrm{PI}-\mathrm{K}$ & 0.242 & 7.716 & 0.741 & 0.084 & 15.773 & 0.999 \\
\hline PE-K & 0.350 & 7.876 & 0.962 & 0.097 & 12.821 & 1.000 \\
\hline SD-K & 0.188 & 5.158 & 0.802 & 0.102 & 9.597 & 0.998 \\
\hline $\mathrm{Pl}-\mathrm{F}$ & 0.213 & 7.697 & 0.702 & 0.069 & 14.025 & 0.999 \\
\hline PE-F & 0.419 & 8.792 & 0.994 & 0.084 & 11.561 & 1.000 \\
\hline SD-F & 0.242 & 5.177 & 0.869 & 0.099 & 8.104 & 0.999 \\
\hline
\end{tabular}

coconut shells or wood and is widely used for the cleanup of contaminated water and wastewater, is usually an expensive material. Its production cost is mainly related to the reactivation process and is increased when high quality activated carbon is needed (Mohan and Chander, 2006; Quintelas et al., 2008; Al-Lagtah et al., 2016).

Figures 4-6 show the adsorption rates of phenols, in $\mathrm{mg} \cdot \mathrm{g}^{-1} \cdot \mathrm{h}^{-1}$, for non-modified, $\mathrm{KOH}$-modified and $\mathrm{FeCl}_{3}$ modified biochars, respectively. It is seen from these figures that:

- For all adsorbents used the adsorption rate of phenols increases with decreasing adsorbent concentration.

- The highest adsorption rate of phenols, $2.74 \mathrm{mg} \cdot \mathrm{g}^{-1} \cdot \mathrm{h}^{-1}$ at equilibrium, is shown for $0.5 \mathrm{mg} \cdot \mathrm{L}^{-1} \mathrm{PI}-\mathrm{K}$ biochar concentration (Figure 5).

- The KOH-modified biochars exhibited the highest phenol removal capacity compared to $\mathrm{FeCl}_{3}$-modified and nonmodified biochars. More specifically, biochar PI-K exhibited the highest adsorption rate compared to biochars $\mathrm{PE}-\mathrm{K}$ and SD-K, for all adsorbent concentrations tested (Figure 5). A similar trend was also noticed for $\mathrm{FeCl}_{3}$-modified biochars (Figure 6) and non-modified biochars (Figure 4).

- Activated carbon shows almost identical adsorption rates with PI biochar, namely $1.28,1.20,0.78$, and $0.45 \mathrm{mg} \cdot \mathrm{g}^{-1} \cdot \mathrm{h}^{-1}$, for $0.5,1,2$, and $5 \mathrm{~g} \cdot \mathrm{L}^{-1}$, respectively (Figure 4).

Biochar PI-K shows the highest phenol adsorption capacity due to its highest surface area and porosity i.e., $572.4 \mathrm{~m}^{2} \cdot \mathrm{g}^{-1}$ and $49.8 \%$, respectively. For biochars exhibiting lower surface area and porosity such as $\mathrm{PE}-\mathrm{K}\left(397.3 \mathrm{~m}^{2} \cdot \mathrm{g}^{-1}\right.$ and $34.7 \%$, respectively) the adsorption capacity decreases accordingly. Similar behavior has been reported by Dai et al. (2013) for biochars produced from wetland plant residues. It is known that the potential of biochar as adsorbent in batch systems depends on its structure, its specific surface area and the available active sorption sites, properties which are affected by modification (Qu et al., 2013).

The main mechanism affecting adsorption of phenols on biochars is most probably the hydrophobic sorption on biochar 
TABLE 4 | Percentage phenol adsorption on biochars PI, PE, SD and modified biochars PI-K, PE-K, SD-K or PI-F, PE-F, SD-F for various adsorbent concentrations $\left(0.5,1,2\right.$, and $\left.5 \mathrm{~g} \cdot \mathrm{L}^{-1}\right)$.

\begin{tabular}{lcccccccccc}
\hline Adsorbent concentration, $\mathbf{g} \cdot \mathbf{L}^{-1}$ & \multicolumn{8}{c}{ Percentage phenol adsorption } \\
\cline { 2 - 10 } & PI & PE & SD & PI-K & PE-K & SD-K & PI-F & PE-F & SD-F & AC* \\
\hline 0.5 & 14.6 & 11.1 & 9.9 & 32.8 & 24.4 & 18.6 & 23.4 & 17.6 & 11.6 & 15.2 \\
1 & 29.5 & 23.2 & 20.2 & 53.9 & 37.6 & 28.5 & 43.9 & 28.4 & 21.8 & 28.6 \\
2 & 36.9 & 27.4 & 25.8 & 61.3 & 51.8 & 33.7 & 50.3 & 47.1 & 28.5 & 36.1 \\
5 & 51.3 & 39.3 & 31.8 & 76.6 & 61.7 & 46.2 & 67.4 & 55.4 & 38.6 & 52.7 \\
\hline
\end{tabular}

${ }^{*}$ Activated carbon.

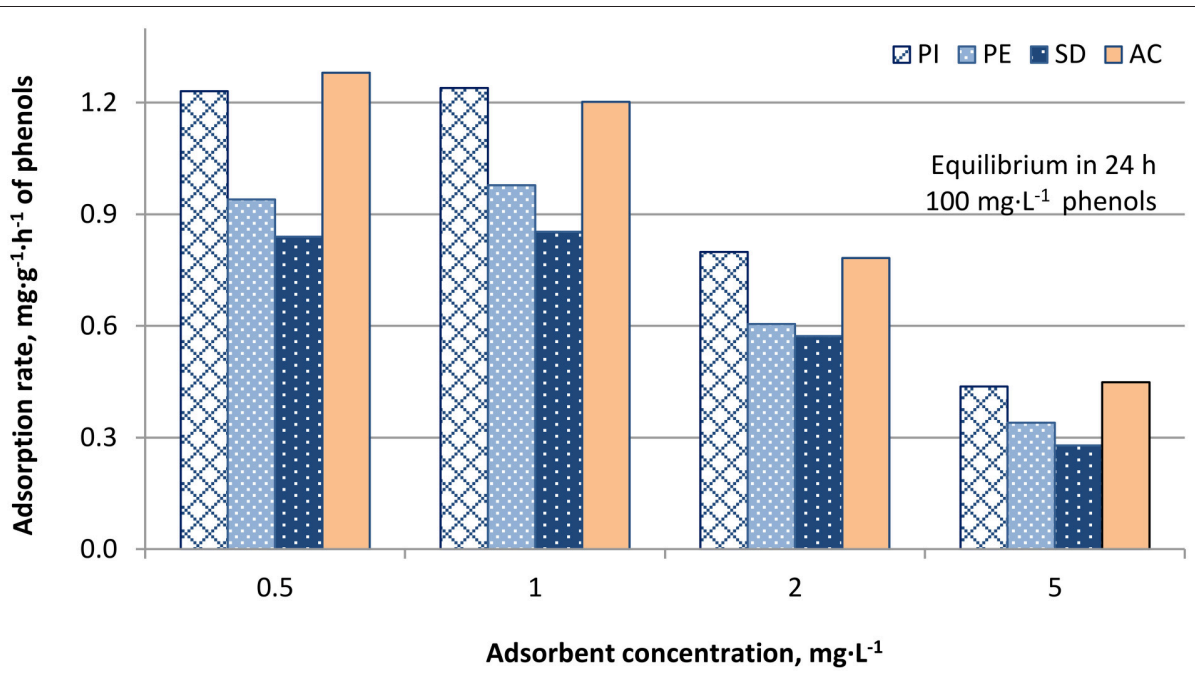

FIGURE 4 | Adsorption rates, $\mathrm{mg} \cdot \mathrm{g}^{-1} \cdot \mathrm{h}^{-1}$, of phenols on biochars PI, PE, and SD for adsorbent concentration $0.5,1,2$, and $5 \mathrm{~g} \cdot \mathrm{L}^{-1}$ (AC: activated carbon, used as reference adsorbent).

surface which is also related to their increased carbon content and the number of oxygenated functional groups (Yu et al., 2015; Oh and Seo, 2016). Also aromatic hydrocarbons present in phenols can be covalently bonded to surfaces of biochar (Cornelissen et al., 2005).

\section{Phenol Sorption Isotherm Models}

In order to describe adsorption of phenols on biochars, the Freundlich and Langmuir models have been used. The Freundlich model, which assumes a multilayer sorption on heterogeneous adsorbent surface, is described by Equation (3):

$$
\log \mathrm{q}_{\mathrm{e}}=\log \mathrm{K}_{\mathrm{f}}+\frac{1}{\mathrm{n}} \log \mathrm{C}_{\mathrm{e}}
$$

where $\mathrm{q}_{\mathrm{e}}\left(\mathrm{mg} \cdot \mathrm{g}^{-1}\right)$ is the uptake of phenol per unit weight of adsorbent in equilibrium, $\mathrm{C}_{e}\left(\mathrm{mg} \cdot \mathrm{L}^{-1}\right)$ is the equilibrium concentration of phenol in solution, $\mathrm{K}_{\mathrm{f}}\left(\mathrm{L} \cdot \mathrm{g}^{-1}\right)$ is the constant related to the adsorption capacity of the adsorbent and $1 / \mathrm{n}$ is the constant related to the adsorption intensity.

The Langmuir model, which assumes a monolayer adsorption on a homogenous surface when the adsorbent has a constant number of adsorption sites, is described by Equation (4):

$$
\frac{\mathrm{C}_{\mathrm{e}}}{\mathrm{q}_{\mathrm{e}}}=\frac{1}{\mathrm{bq}_{\max }}+\frac{1}{\mathrm{q}_{\max }} \mathrm{C}_{\mathrm{e}}
$$

where $\mathrm{C}_{e}\left(\mathrm{mg} \cdot \mathrm{L}^{-1}\right)$ is the equilibrium concentration of phenol in solution, $\mathrm{q}_{\mathrm{e}}\left(\mathrm{mg} \cdot \mathrm{g}^{-1}\right)$ is the uptake of phenol per unit weight of adsorbent in equilibrium, $\mathrm{q}_{\max }$ is the maximum adsorption capacity of the adsorbent $\left(\mathrm{mg} \cdot \mathrm{g}^{-1}\right)$ and $\mathrm{b}\left(\mathrm{L} \cdot \mathrm{mg}^{-1}\right)$ is the Langmuir constant related to the energy of the adsorption.

The Freundlich and Langmuir isotherms for phenol adsorption on biochars PI, PE, SD and modified biochars PI-K, PE-K, SD-K or PI-F, PE-F, SD-F, are presented in Figures 7, $\mathbf{8}$, respectively. The respective equations and the correlation coefficients $R^{2}$ are also shown in these figures which were prepared using the equilibrium concentration of phenols in solution for four different adsorbent concentrations (Table 4). It is shown that for all investigated biochars the Freundlich model gives a better fit compared to Langmuir model, while the highest $R^{2}$ values correspond to the PI-K biochar, which shows the highest phenol adsorption efficiency.

The Freundlich model describes very well sorption probably due to surface heterogeneity of the produced biochars, including 


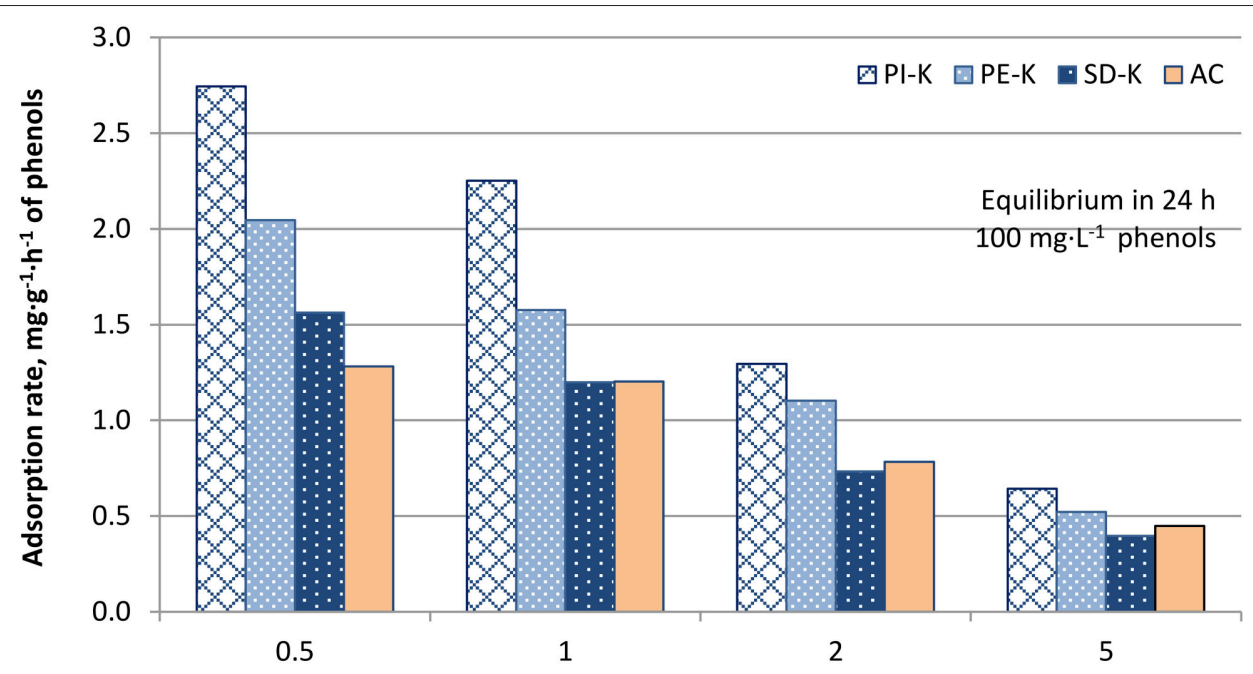

Adsorbent concentration, $\mathrm{mg} \cdot \mathrm{L}^{-1}$

FIGURE 5 | Adsorption rates, $\mathrm{mg} \cdot \mathrm{g}^{-1} \cdot \mathrm{h}^{-1}$, of phenols on biochars PI-K, PE-K, and SD-K for adsorbent concentration $0.5,1,2$, and $5 \mathrm{~g} \cdot \mathrm{L}^{-1}$ (AC: activated carbon, used as reference adsorbent).

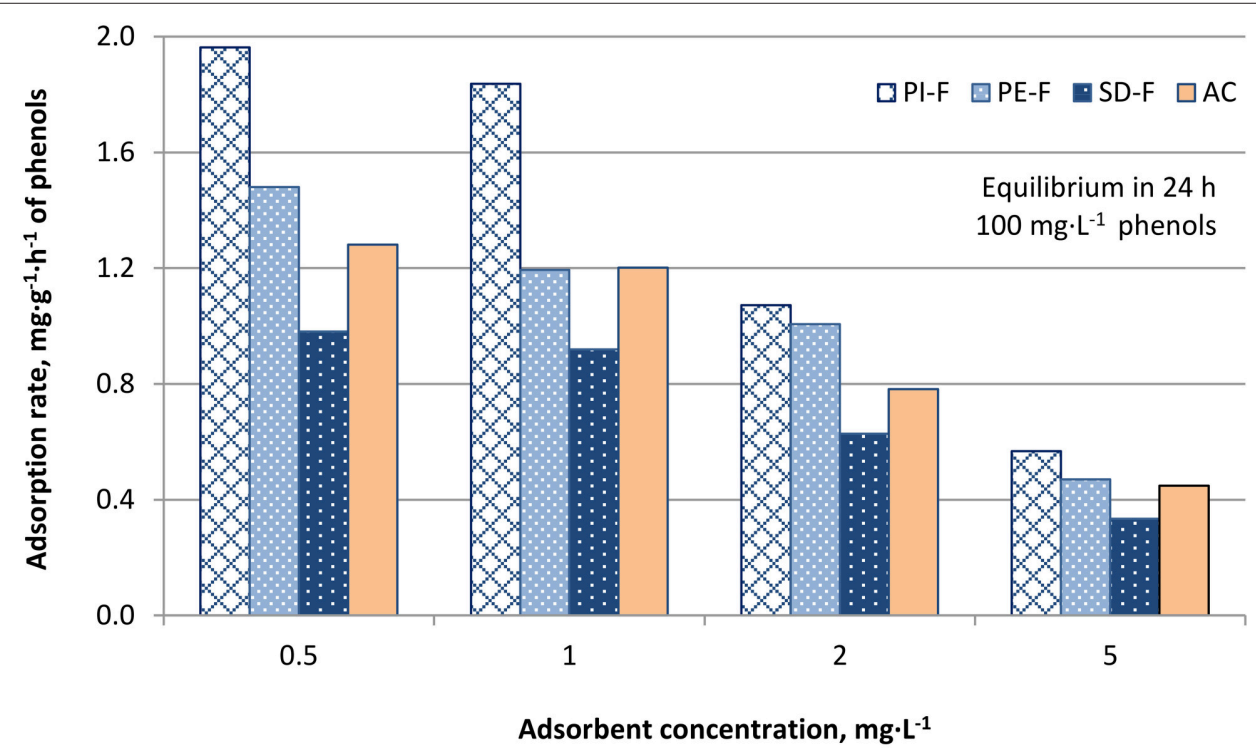

FIGURE 6 | Adsorption rates, $\mathrm{mg} \cdot \mathrm{g}^{-1} \cdot \mathrm{h}^{-1}$, of phenols on biochars PI-F, PE-F, and SD-F for adsorbent concentration $0.5,1,2$, and $5 \mathrm{~g} \cdot \mathrm{L}^{-1}$ (AC: activated carbon, used as reference adsorbent).

pore size distribution and presence of functional groups (Girods et al., 2009). The Langmuir model is not suitable to describe adsorption of phenols on biochars as also discussed in other relevant studies (Huang and Chen, 2010; Han et al., 2013; Agrafioti et al., 2014).

Thus, the Freundlich Equation (3) for PI-K biochar $\left(\log \mathrm{K}_{\mathrm{f}}=\right.$ $-0.78,1 / \mathrm{n}=1.45$ ) becomes

$$
\begin{aligned}
& \log \mathrm{q}_{\mathrm{e}}=1.45 \log \mathrm{C}_{\mathrm{e}}-0.78 \Leftrightarrow \\
& \mathrm{q}_{\mathrm{e}}=0.17 \mathrm{C}_{\mathrm{e}}^{1.45}
\end{aligned}
$$

\section{CONCLUSIONS}

Three different agricultural wastes, namely pistachio shells, pecan shells and pine wood sawdust were pyrolyzed for the production of biochars which were also chemically modified with the use of $1 \mathrm{M} \mathrm{KOH}$ or $1 \mathrm{M} \mathrm{FeCl}_{3}$ and tested for the removal of phenols from synthetic solutions.

The results of this study show that $\mathrm{KOH}$ is a more efficient biochar modifier compared to $\mathrm{FeCl}_{3}$, since it results in increased carbon content, porosity and surface area. Phenols are adsorbed 

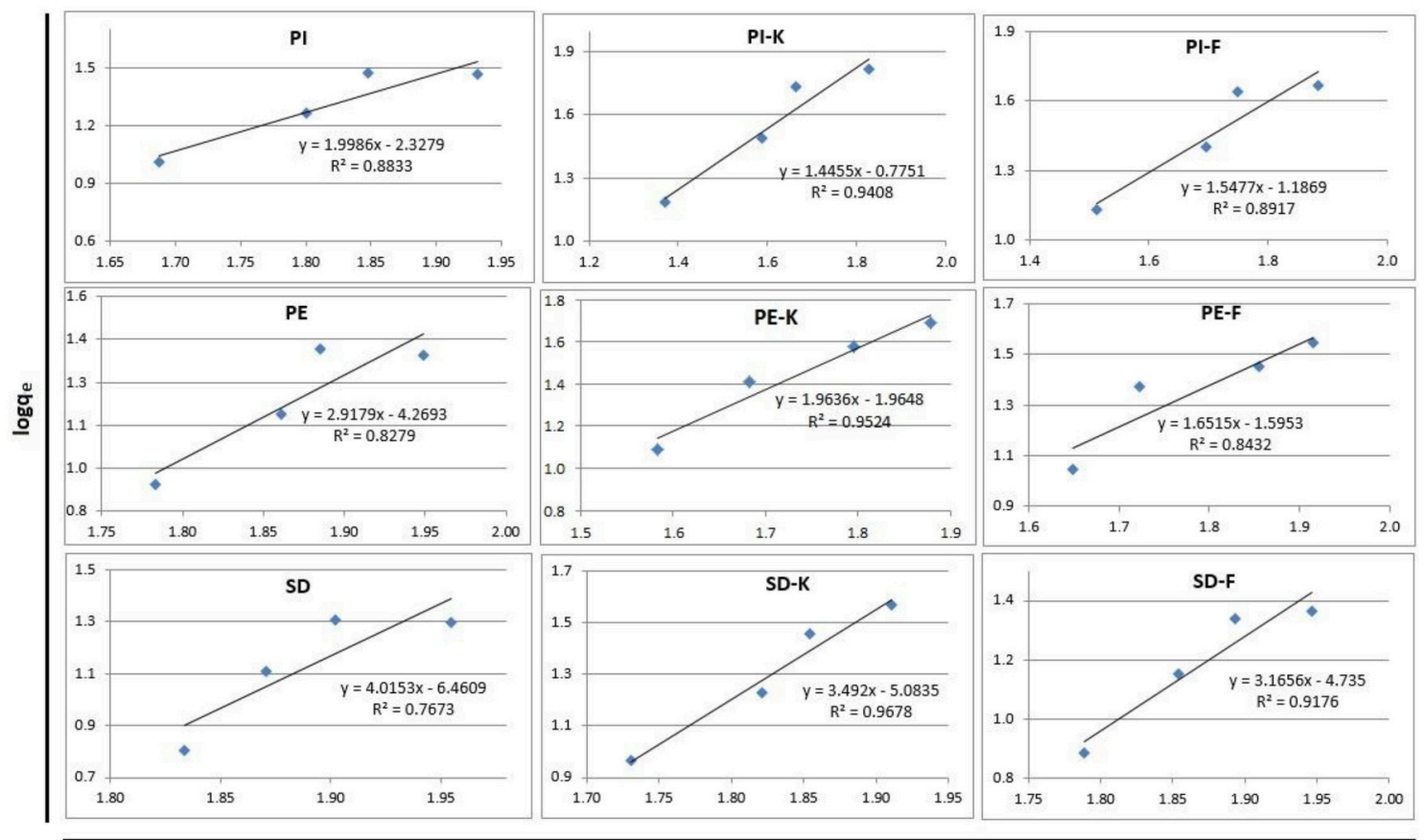

$\log \mathrm{Ce}_{\mathrm{e}}$

FIGURE 7 | Freundlich isotherms for phenols adsorption on biochars PI, PE, SD, and modified biochars PI-K, PE-K, SD-K or PI-F, PE-F, SD-F.
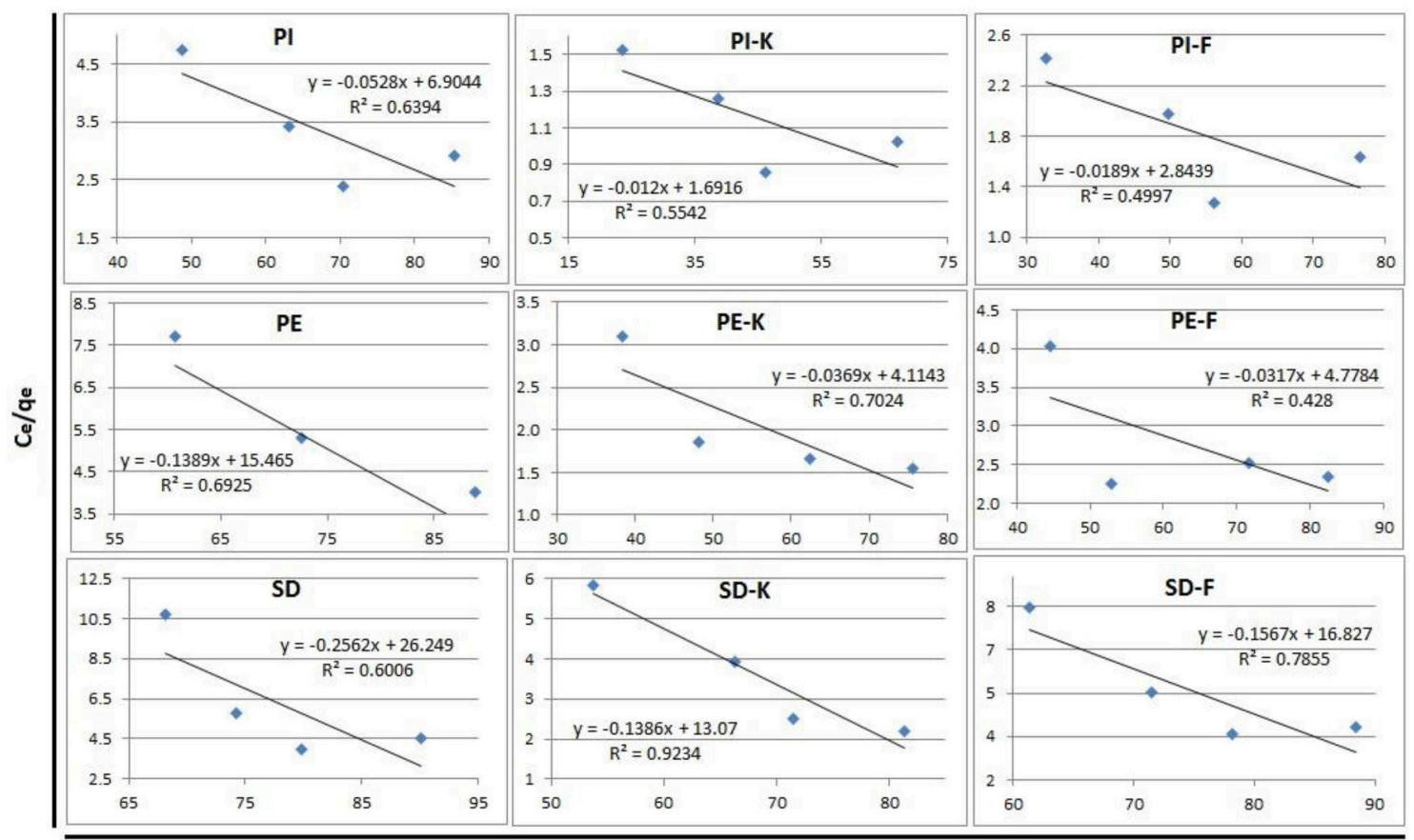

$\mathrm{Ce}, \mathrm{mg} \cdot \mathrm{L}^{-1}$

FIGURE 8 | Langmuir isotherms for phenols adsorption on biochars PI, PE, SD, and modified biochars PI-K, PE-K, SD-K or PI-F, PE-F, SD-F. 
on $\mathrm{KOH}$-modified biochars following the sequence $\mathrm{PI}-\mathrm{K}>\mathrm{PE}$ $\mathrm{K}>\mathrm{SD}-\mathrm{K}$.

Modification of PI-biochar with $\mathrm{KOH}$ or $\mathrm{FeCl}_{3}$ results in better phenol adsorption efficiency compared to commercial activated carbon.

Porosity and surface area are considered the main parameters that affect biochar properties and thus define their potential in environmental applications, including adsorption of contaminants from solutions. The use of analytical techniques, XRD, SEM, and FTIR, offers significant insights regarding the morphology of the produced biochars in terms of content of organic carbon, degree of homogeneity, and

\section{REFERENCES}

Agrafioti, E., Bouras, G., Kalderis, D., and Diamadopoulos, E. (2013). Biochar production by sewage sludge pyrolysis. J. Anal. Appl. Pyrol. 101, 72-78. doi: 10.1016/j.jaap.2013.02.010

Agrafioti, E., Kalderis, D., and Diamadopoulos, E. (2014). Arsenic and chromium removal from water using biochars derived from rice husk, organic solid wastes and sewage sludge. J. Environ. Manage. 133, 309-314. doi: 10.1016/j.jenvman.2013.12.007

Al-Lagtah, N. M. A., Al-Muhtaseb, A. H., Ahmad, M. N. M., and Salameh, Y. (2016). Chemical and physical characteristics of optimal synthesised activated carbons from grass-derived sulfonated lignin versus commercial activated carbons. Microporous Mesoporous Mater. 225, 504-514. doi: 10.1016/j.micromeso.2016.01.043

Angin, D., Köse, T. E., and Selengil, U. (2013). Production and characterization of activated carbon prepared from safflower seed cake biochar and its ability to absorb reactive dyestuff. Appl. Surf. Sci. 280, 705-710. doi: 10.1016/j.apsusc.2013.05.046

Angin, D., and Şensöz, S. (2014). Effect of pyrolysis temperature on chemical and surface properties of biochar of rapeseed (Brassica napus L.). Int. J. Phytoremediat. 16, 684-693. doi: 10.1080/15226514.2013.856842

Bayramoglu, G., Gursel, I., Tunali, Y., and Arica, M. Y. (2009). Biosorption of phenol and 2-chlorophenol by Funalia trogii pellets. Bioresour. Technol. 100, 2685-2691. doi: 10.1016/j.biortech.2008.12.042

Beesley, L., Moreno-Jimenez, E., Gomez-Eyles, J. L., Harris, E., Robinson, B., and Sizmur, T. (2011). A review of biochars' potential role in the remediation, revegetation and restoration of contaminated soils. Environ. Pollut. 159, 3269-3282. doi: 10.1016/j.envpol.2011.07.023

Box, J. D. (1983). Investigation of the Folin-Ciocalteau phenol reagent for the determination of the polyphenolic substances in natural waters. Water Res. 17, 511-525. doi: 10.1016/0043-1354(83)90111-2

Brewer, C. E., Chuang, V. J., Masiello, C. A., Gonnermann, H., Gao, X., Dugan, B., et al. (2014). New approaches to measuring biochar density and porosity. Biomass Bioenerg. 66, 176-185. doi: 10.1016/j.biombioe.2014. 03.059

Canadian Council of Ministers of the Environment (2007). Canadian Soil Quality Guidelines for the Protection of Environmental and Human Health. Winnipeg, MB: Excerpt from publication No 1299.

Cao, X., and Harris, W. (2010). Properties of dairy-manure-derived biochar pertinent to its potential use in remediation. Bioresour. Technol. 101, 5222-5228. doi: 10.1016/j.biortech.2010.02.052

Cayuela, M. L., Sánchez-Monedero, M. A., Roig, A., Hanley, K., Enders, A., and Lehmann, J. (2013). Biochar and denitrification in soils: when, how much and why does biochar reduce $\mathrm{N}_{2} \mathrm{O}$ emissions? Sci. Reports 3:1732. doi: $10.1038 /$ srep01732

Cornelissen, G., Gustafsson, Ö., Bucheli, T. D., Jonker, M. T. O., Koelmans, A. A., and van Noort, P. C. M. (2005). Extensive sorption of organic compounds to black carbon, coal, and kerogen in sediments and soils: mechanisms and consequences for distribution, bioaccumulation, and biodegradation. Environ. Sci. Technol. 39, 6881-6895. doi: 10.1021/es050191b

Dai, Z., Meng, J., Muhammad, N., Liu, X., Wang, H., He, Y., et al. (2013). The potential feasibility for soil improvement, based on the properties of biochars existence of porous structure, factors which determine the number of available active sites and assess their adsorption efficiency.

Finally, kinetic and equilibrium studies show that the pseudosecond order model fits best adsorption kinetics data, while the Freundlich model describes very well adsorption of phenols on biochars.

\section{AUTHOR CONTRIBUTIONS}

Both authors listed, have made substantial, direct and intellectual contribution to the work, and approved it for publication.

pyrolyzed from different feedstocks. J. Soils Sediments 13, 989-1000. doi: 10.1007/s11368-013-0698-y

Dari, B., Nair, V. D., Colee, J., Harris, W. G., and Mylavarapu, R. (2015). Estimation of phosphorus isotherm parameters: a simple and cost-effective procedure. Front. Environ. Sci 3:70. doi: 10.3389/fenvs.2015.00070

Dehkhoda, A. M., Ellis, N., and Gyenge, E. (2016). Effect of activated biochar porous structure on the capacitive deionization of $\mathrm{NaCl}$ and $\mathrm{ZnCl}_{2}$ solutions. Micropor. Mesopor. Mat. 224, 217-228. doi: 10.1016/j.micromeso.2015.11.041

Devi, P., and Saroha, A. K. (2015). Simultaneous adsorption and dechlorination of pentachlorophenol from effluent by Ni-ZVI magnetic biochar composites synthesized from paper mill sludge. Chem. Eng. J. 271, 195-203. doi: 10.1016/j.cej.2015.02.087

Di Bene, C., Pellegrino, E., Debolini, M., Silvestri, N., and Bonari, E. (2013). Short- and long-term effects of olive mill wastewater land spreading on soil chemical and biological properties. Soil Biol. Biochem. 56, 21-30. doi: 10.1016/j.soilbio.2012.02.019

Environmental Protection Agency (1995). Final National Pollutant Discharge Elimination System Storm Water Multi-Sector General Permit for Industrial Activities, Federal Register, Vol. 60. Washington, DC: Environmental Protection Agency.

Frišták, V., Pipíška, M., Lesný, J., Soja, G., Friesl-Hanl, W., and Packová, A. (2015). Utilization of biochar sorbents for $\mathrm{Cd}^{2+}, \mathrm{Zn}^{2+}$, and $\mathrm{Cu}^{2+}$ ions separation from aqueous solutions: comparative study. Environ. Monit. Assess. 187, 4093. doi: 10.1007/s10661-014-4093-y

Ghani, W. A. W. A. K., Mohd, A., Da Silva, G., Bachmann, R. T., Taufiq-Yap, Y. H., Rashid, U., et al. (2013). Biochar production from waste rubber-wood-sawdust and its potential use in $\mathrm{C}$ sequestration: chemical and physical characterization. Ind. Crop. Prod. 44, 18-24. doi: 10.1016/j.indcrop.2012.10.017

Girods, P., Dufour, A., Fierro, V., Rogaume, Y., Rogaume, C., Zoulalian, A., et al. (2009). Activated carbons prepared from wood particleboard wastes: characterisation and phenol adsorption capacities. J. Hazard. Mater. 166, 491-501. doi: 10.1016/j.jhazmat.2008.11.047

Gray, M., Johnson, M. G., Dragila, M. I., and Kleber, M. (2014). Water uptake in biochars: the roles of porosity and hydrophobicity. Biomass Bioenerg. 61, 196-205. doi: 10.1016/j.biombioe.2013.12.010

Greek Government Gazette (2007). Modification of CMD (Common Ministerial Decision) on Quality of Drinking Water, in Accordance with 98/83/EC Directive. 630 (issue $B^{\prime}$ ), 26-4-2007.

Han, Y., Boateng, A. A., Qi, P. X., Lima, I. M., and Chang, J. (2013). Heavy metal and phenol adsorptive properties of biochars from pyrolyzed switchgrass and woody biomass in correlation with surface properties. J. Environ. Manage. 118, 196-204. doi: 10.1016/j.jenvman.2013.01.001

Ho, Y.-S. (2006a). Review of second-order models for adsorption systems. $J$. Hazard. Mater. B 136, 681-689. doi: 10.1016/j.jhazmat.2005.12.043

Ho, Y.-S. (2006b). Second-order kinetic model for the sorption of cadmium onto tree fern: a comparison of linear and non-linear methods. Water Res. 40, 119-125. doi: 10.1016/j.watres.2005.10.040

Ho, Y.-S., and McKay, G. (1999). Pseudo-second order model for sorption processes. Process Biochem. 34, 451-465. doi: 10.1016/S0032-9592(98)00112-5

Huang, W., and Chen, B. (2010). Interaction mechanisms of organic contaminants with burned straw ash charcoal. J. Environ. Sci. 22, 1586-1594. doi: 10.1016/S1001-0742(09)60293-X 
Hui, C.-W., Chen, B., and McKay, G. (2003). Pore-Surface Diffusion Model for Batch Adsorption Processes. Langmuir 19, 4188-4196. doi: 10.1021/la026624v

Inyang, M., and Dickenson, E. (2015). The potential role of biochar in the removal of organic and microbial contaminants from potable and reuse water: a review. Chemosphere 134, 232-240. doi: 10.1016/j.chemosphere.2015.03.072

Inyang, M., Gao, B., Zimmerman, A., Zhang, M., and Chen, H. (2014). Synthesis, characterization, and dye sorption ability of carbon nanotube- biochar nanocomposites. Chem. Eng. J. 236, 39-46. doi: 10.1016/j.cej.2013.09.074

Karakoyun, N., Kubilay, S., Aktas, N., Turhan, O., Kasimoglu, M., Yilmaz, S., et al. (2011). Hydrogel-Biochar composites for effective organic contaminant removal from aqueous media. Desalination 280, 319-325. doi: 10.1016/j.desal.2011.07.014

Kim, P., Johnson, A. M., Essington, M. E., Radosevich, M., Kwon, W.-T., Lee, S.-H., et al. (2013). Effect of pH on surface characteristics of switchgrassderived biochars produced by fast pyrolysis. Chemosphere 90, 2623-2630. doi: 10.1016/j.chemosphere.2012.11.021

Kloss, S., Zehetner, F., Oburger, E., Buecker, J., Kitzler, B., Wenzel, W. W., et al. (2014). Trace element concentration in leachates and mustard plant tissue (Sinapis alba L.) after biochar application to temperate soil. Sci. Total Environ. 481, 498-508. doi: 10.1016/j.scitotenv.2014.02.093

Komnitsas, K., Zaharaki, D., Bartzas, G., Kaliakatsou, G., and Kritikaki, A. (2016). Efficiency of pecan shells and sawdust biochar on $\mathrm{Pb}$ and $\mathrm{Cu}$ adsorption. Desalin. Water Treat. 57, 3237-3246. doi: 10.1080/19443994.2014.981227

Komnitsas, K., Zaharaki, D., Pyliotis, I., Vamvuka, D., and Bartzas, G. (2015). Assessment of pistachio shell biochar quality and its potential for adsorption of heavy metals. Waste Biomass Valor. 6, 805-816. doi: 10.1007/s12649-0159364-5

Li, Y., Du, Q., Wang, X., and Xia, Y. (2010). Removal of lead from aqueous solution by activated carbon prepared from Entermorpha prolifera by zinc chloride activation. J. Hazard. Mater. 183, 583-589. doi: 10.1016/j.jhazmat.2010.07.063

Liu, P., Liu, W.-J., Jiang, H., Chen, J.-J., Li, W.-W., and Yu, H.-Q. (2012). Modification of bio-char derived from fast pyrolysis of biomass and its application in removal of tetracycline from aqueous solution. Bioresource Technol. 121, 235-240. doi: 10.1016/j.biortech.2012.06.085

Liu, Y., Chen, J., Chen, M., Zhang, B., Wu, D., and Cheng, Q. (2015). Adsorption characteristics and mechanism of sewage sludge-derived adsorbent for removing sulfonated methyl phenol resin in wastewater. RSC Adv. 5, 76160-76169. doi: 10.1039/C5RA17125C

Liu, Z., Quek, A., Hoekman, S. K., and Balasubramanian, R. (2013). Production of solid biochar fuel from waste biomass by hydrothermal carbonization. Fuel 103, 943-949. doi: 10.1016/j.fuel.2012.07.069

Lou, L., Wu, B., Wang, L., Luo, L., Xu, X., Hou, J., et al. (2011). Sorption and ecotoxicity of pentachlorophenol polluted sediment amended with rice-straw derived biochar. Bioresource Technol. 102, 4036-4041. doi: 10.1016/j.biortech.2010.12.010

Manyà, J. J. (2012). Pyrolysis for biochar production. A review to establish current knowledge gaps and research needs. Environ. Sci. Technol. 46, 7939-7954. doi: $10.1021 / \mathrm{es} 301029 \mathrm{~g}$

Mayer, Z. A., Eltom, Y., Stennett, D., Schroder, E., Apfelbacher, A., and Hornung, A. (2014). Characterization of engineered biochar for soil management. Environ. Prog. Sustain. Energy 33, 490-496. doi: 10.1002/ep.11788

Mimmo, T., Panzacchi, P., Baratieria, M., Davies, C. A., and Tonon, G. (2014). Effect of pyrolysis temperature on miscanthus (Miscanthus X giganteus) biochar physical, chemical and functional properties. Biomass Bioenerg. 62, 149-157. doi: 10.1016/j.biombioe.2014.01.004

Mohan, D., and Chander, S. (2006). Removal and recovery of metal ions from acid mine drainage using lignite-A low cost sorbent. J. Hazard. Mater. 137, 1545-1553. doi: 10.1016/j.jhazmat.2006.04.053

Mohan, D., Pittman, C. U., Bricka, M., Smith, F., Yancey, B., Mohammad, J., et al. (2007). Sorption of arsenic, cadmium, and lead by biochars produced from fast pyrolysis of wood and bark during bio-oil production. J. Colloid Interface Sci. 310, 57-73. doi: 10.1016/j.jcis.2007.01.020

Moussavi, G., and Khosravi, R. (2012). Preparation and characterization of a biochar from pistachio hull biomass and its catalytic potential for ozonation of water recalcitrant contaminants. Bioresour. Technol. 119, 66-71. doi: 10.1016/j.biortech.2012.05.101

Mubarik, S., Saeed, A., Athar, M. M., and Iqbal, M. (2016). Characterization and mechanism of the adsorptive removal of 2,4,6-trichlorophenol by biochar prepared from sugarcane baggase. J. Ind. Eng. Chem. 33, 115-121. doi: 10.1016/j.jiec.2015.09.029
Oh, S.-Y., and Seo, Y.-D. (2016). Sorption of halogenated phenols and pharmaceuticals to biochar: affecting factors and mechanisms. Environ. Sci. Pollut. Res. 23, 951-961. doi: 10.1007/s11356-015-4201-8

Qian, W., Zhao, A.-Z., and Xu, R.-K. (2013). Sorption of As(V) by AluminumModified crop straw-derived biochars. Water Air Soil Pollut. 224:1610. doi: 10.1007/s11270-013-1610-5

Qu, X., Alvarez, P. J. J., and Li, Q. (2013). Applications of nanotechnology in water and wastewater treatment. Water Res. 47, 3931-3946. doi: 10.1016/j.watres.2012.09.058

Quintelas, C., Fernandes, B., Castro, J., Figueiredo, H., and Tavares, T. (2008). Biosorption of $\mathrm{Cr}(\mathrm{VI})$ by three different bacterial species supported on granular activated carbon-A comparative study. J. Hazard. Mater. 153, 799-809. doi: 10.1016/j.jhazmat.2007.09.027

Samsuri, A. W., Sadegh-Zadeh, F., and Seh-Bardan, B. J. (2013). Adsorption of $\mathrm{As}(\mathrm{III})$ and $\mathrm{As}(\mathrm{V})$ by Fe coated biochars and biochars produced from empty fruit bunch and rice husk. J.E.C.E. 1, 981-988. doi: 10.1016/j.jece.2013.08.009

Sánchez, M. E., Lindao, E., Margaleff, D., Martínez, O., and Morán, A. (2009). Pyrolysis of agricultural residues from rape and sunflowers: production and characterization of bio-fuels and biochar soil management. J. Anal. Appl. Pyrolysis 85, 142-144. doi: 10.1016/j.jaap.2008.11.001

Sánchez-García, M., Roig, A., Sánchez-Monedero, M. A., and Cayuela, M. L. (2014). Biochar increases soil $\mathrm{N}_{2} \mathrm{O}$ emissions produced by nitrificationmediated pathways. Front. Environ. Sci. 2:25. doi: 10.3389/fenvs.2014.00025

Sharma, R. K., Wooten, J. B., Baliga, V. L., Lin, X., Geoffrey Chan, W., and Hajaligol, M. R. (2004). Characterization of chars from pyrolysis of lignin. Fuel 83, 1469-1482. doi: 10.1016/j.fuel.2003.11.015

Socrates, G. (2001). Infrared and Raman Characteristic Group Frequencies, 3rd Edn. Chichester: John Wiley \& Sons Ltd.

Steiner, C., Glaser, B., Teixeira, W. G., Lehmann, J., Blum, W. E. H., and Zech, W. (2008). Nitrogen retention and plant uptake on a highly weathered central Amazonian Ferralsol amended with compost and charcoal. J. Plant Nutr. Soil Sci. 171, 893-899. doi: 10.1002/jpln.200625199

Sun, L., Chen, D., Wanb, S., and Yu, Z. (2015). Performance, kinetics, and equilibrium of methylene blue adsorption on biochar derived from eucalyptus saw dust modified with citric, tartaric, and acetic acids. Bioresource Technol. 198, 300-308. doi: 10.1016/j.biortech.2015.09.026

Tripathi, M., Sahu, J. N., and Ganesan, P. (2016). Effect of process parameters on production of biochar from biomass waste through pyrolysis: a review. Renew. Sust. Energ. Rev. 55, 467-481. doi: 10.1016/j.rser.2015.10.122

Usman, A. R. A., Ahmad, M., El-Mahrouky, M., Al-Omran, A., Ok, Y. S., Sallam, A. S., et al. (2016). Chemically modified biochar produced from conocarpus waste increases $\mathrm{NO}_{3}$ removal from aqueous solutions. Environ. Geochem. Health 38 511-521. doi: 10.1007/s10653-015-9736-6

Wang, S., Gao, B., Li, Y., Mosa, A., Zimmerman, A. R., Ma, L. Q., et al. (2015). Manganese oxide-modified biochars: preparation, characterization, and sorption of arsenate and lead. Bioresource Technol. 181, 13-17. doi: 10.1016/j.biortech.2015.01.044

Wang, X., Sato, T., and Xing, B. (2006). Competitive sorption of pyrene on wood chars. Environ. Sci. Technol. 40, 3267-3272. doi: 10.1021/es0521977

Yang, G.-X., and Jiang, H. (2014). Amino modification of biochar for enhanced adsorption of copper ions from synthetic wastewater. Water Res. 48, 396-405. doi: 10.1016/j.watres.2013.09.050

Yu, Z., Zhou, L., Huang, Y., Song, Z., and Qiu, W. (2015). Effects of a manganese oxide-modified biochar composite on adsorption of arsenic in red soil. $J$. Environ. Manage. 163, 155-162. doi: 10.1016/j.jenvman.2015.08.020

Zahir, H., Naidoo, M., Kostadinova, R.-M., Ortiz, K. A., Sun-Kou, R., and Navarro, A. E. (2015). Decolorization of hair dye by lignocellulosic waste materials from contaminated waters. Front. Environ. Sci. 2:28. doi: 10.3389/fenvs.2014. 00028

Conflict of Interest Statement: The authors declare that the research was conducted in the absence of any commercial or financial relationships that could be construed as a potential conflict of interest.

Copyright $\odot 2016$ Komnitsas and Zaharaki. This is an open-access article distributed under the terms of the Creative Commons Attribution License (CC BY). The use, distribution or reproduction in other forums is permitted, provided the original author(s) or licensor are credited and that the original publication in this journal is cited, in accordance with accepted academic practice. No use, distribution or reproduction is permitted which does not comply with these terms. 